\title{
Hubungan berbagai faktor internal dan eksternal dengan keteraturan pemeriksaan antenatal
}

\author{
Ira Marwati Putri ${ }^{1}$ Lily Marliany Surjadi ${ }^{2}$
}

\begin{abstract}
ABSTRAK
\section{LATAR BELAKANG}

Angka kematian ibu (AKI) di Indonesia masih tinggi, yaitu sebesar 305 per 100.000 kelahiran pada tahun 2015 dan merupakan nomor dua tertinggi di Asia. Untuk itu, pemerintah berupaya melakukan perbaikan, salah satunya dengan Safe Motherhood, salah satu komponennya adalah asuhan antanatal. Departemen Kesehatan mencanangkan minimal 4 kali pemeriksaan selama masa kehamilan, sekali pada trimester pertama, sekali pada trimester kedua dan dua kali pada trimester terakhir. Dengan asuhan antenatal yang baik, diharapkan ibu sehat melalui masa kehamilan dan persalinannya, sehingga AKI dapat diturunkan. Penelitian ini bertujuan untuk melihat hubungan berbagai faktor internal dan eksternal dengan keteraturan pemeriksaan antenatal.
\end{abstract}

\section{METODE}

Penelitian ini merupakan penelitian observasional analitik dengan pendekatan cross sectional. Populasi adalah ibu hamil sehat yang memeriksakan kehamilan di Puskesmas Kebon Jeruk dan Puskesmas Tambora, tanpa penyulit kehamilan. Sampel diambil secara consecutive non random sampling. Instrumen yang digunakan adalah kuesioner dan kemudian dianalisis dengan uji Chi square menggunakan program SPSS for Mac versi 20.0.

\section{HASIL}

Didapatkan total 121 sampel, dan dari faktor internal didapatkan kelompok terbanyak usia 20-35 tahun $(75,2 \%)$, paritas $<2$ orang $(74,4 \%)$, memiliki pengetahuan kurang $(63,6 \%)$ dan sikap negatif (57,9\%). Untuk faktor eksternal didapatkan kelompok terbanyak dengan penghasilan di atas UMR (54,5\%), waktu tempuh ke Puskesmas $<30$ menit $(57,9 \%)$, tidak bekerja $(63,6 \%)$, dan mendapat dukungan suami $(62 \%)$. Didapatkan hubungan yang bermakna antara faktor internal paritas $(p=0,033)$, pengetahuan $(p=0,000)$ dan sikap $(p=0,000)$ serta faktor eksternal penghasilan $(\mathrm{p}=0,000)$, waktu tempuh $(\mathrm{p}=0,015)$ dan dukungan suami $(\mathrm{p}=0,000)$ dengan keteraturan melakukan kunjungan perawatan antenatal.

\section{KESIMPULAN}

Terdapat hubungan antara faktor internal (paritas, sikap dan pengetahuan) dan faktor eksternal (penghasilan, waktu tempuh dan dukungan suami) dengan keteraturan pemeriksaan antenatal.

Kata kunci : pemeriksaan antenatal, faktor internal, faktor eksternal

\author{
${ }^{1}$ Program Studi Kedokteran, \\ Fakultas Kedokteran, \\ Universitas Trisakti \\ ${ }^{2}$ Departemen Obstetri dan \\ Ginekologi, Fakultas Kedokteran, \\ Universitas Trisakti
}

\section{Korespondensi:}

Lily Marliany Surjadi

Departemen Obstetri dan

Ginekologi, Fakultas Kedokteran,

Universitas Trisakti,

Jalan Kyai Tapa No. 260, Grogol,

Jakarta Barat 11440

Email: lily0712@trisakti.ac.id

J Biomedika Kesehat 2019;2(1):27-33

DOI: 10.18051/JBiomedKes.2019.

v2.27-33

pISSN: 2621-539X / eISSN: 2621-5470

Artikel akses terbuka (open access) ini didistribusikan di bawah lisensi Creative Commons Attribution 4.0 International (CC-BY 4.0) 


\section{ABSTRACT}

\section{Relationships of internal and external factors to the regularity of entenatal care}

\section{BACKGROUND}

Maternal mortality rate is still high in Indonesia, that is 305 per 100.000 birth (2015), which is second in Asia. For that reason, government has made efforts for improvements, including Safe Motherhood, which one of the efforts is antenatal care. Health Ministry has stated for minimal 4 times antenatal care during the whole pregnancy, divided as once in the first, once in the second and twice in the third trimester. With good and regular antenatal care, it is hoped that pregnant women will be healthy enough throughout pregnancy and delivery process so MMR can be decreased. This study is aimed to seek for relationships between internal/ external factors and the regularity of antenatal care.

\section{METHODS}

This is an analytic observational study designed as cross sectional. Sample population are healthy pregnant women who have antenatal care at Puskesmas Kebon Jeruk and Puskesmas Tambora, without any pregnancy complications. Sample were recruited by consecutive non random sampling. Data were collected using questionnaires and then were analyzed statistically using Chi square test using SPSS for Mac 20.0 version.

\section{RESULT}

A total of 121 samples were recruited. For internal factors, most sample were groups of $20-35$ years $(75,2 \%)$, parity $<2(74,4 \%)$, with lack of knowledge $(63,6 \%)$ and negative attitude $(57,9 \%)$. For extrernal factors, most sample were groups of income more than minimal regional salary $(54,5 \%)$, with time to reach clinics $<30$ minutes $(57,9 \%)$, unemployed $(63,6 \%)$ and have support from husbands $(62 \%)$. There are significant relationships between internal factor parity $(p=0,033)$, knowledge $(p-0,000)$ and attitude $(p=0,000)$, also external factors income $(p=0.000)$, distance time $(p=0,015)$ and husbands' support ' $(p=0,000)$ with the regularity of antenatal care.

\section{CONCLUSION}

There are relationships of internal (parity, knowledge, attitude) and external factos (income, distance time, husbands' support) with the regularity of antenatal care.

Keywords : antenatal care, internal factors, external factors

\section{PENDAHULUAN}

Kehamilan merupakan proses alamiah yang dialami wanita. Lama kehamilan berlangsung sampai cukup bulan (aterm) adalah sekitar 40 minggu dihitung dari hari pertama haid terakhir. Selama masa kehamilan, seorang ibu hamil mengalami perubahan anatomis dan fisiologis pada tubuhnya, yang terjadi segera setelah fertilisasi dan berlanjut terus selama kehamilan, dan biasanya merupakan respon terhadap adanya janin dan plasenta. Pemantauan selama masa kehamilan memerlukan asuhan antenatal yang baik, yang mencakup pengetahuan dan kemampuan untuk mengenali perubahan fisiologik yang berhubungan dengan proses kehamilan. ${ }^{(1)}$

Angka kematian ibu di Indonesia masih tinggi, bahkan masih menempati urutan kedua di Asia. Berdasarkan Survei Demografi dan Kesehatan Indonesia (SDKI) pada tahun 2015 AKI menurun di bandingkan pada tahun 2012, dimana AKI pada tahun 2012 sebesar 359 per 100.000 kelahiran hidup, sedangkan pada tahun 2015 AKI menjadi 305 per 100.000 kelahiran hidup. ${ }^{(2)}$

Pemerintah berupaya menurunkan angka kematian ibu dengan berbagai program.
Salah satunya adalah dengan program Safe Motherhood, yang mencakup 4 pelayanan utama yang berhubungan dengan kesehatan ibu yaitu, pelayanan Keluarga Berencana, pelayanan antenatal, pelayanan persalinan yang bersih dan aman serta pelayanan obstetri esensial.(3) Pelayanan antenatal merupakan upaya preventif untuk mengoptimalkan hasil luaran maternal dan neonatal melalui rangkaian pemeriksaan rutin selama kehamilan. Untuk kehamilan yang normal tanpa penyulit, pemeriksaan kehamilan cukup dilakukan sebanyak 4 kali dengan jadwal, sekali kunjungan pada usia kehamilan di bawah 28 minggu, sekali kunjungan pada usia kehamilan antata 28-36 minggu dan dua kali kunjungan pada kehamilan di atas 36 minggu. Dengan cara demikian, dapat ditelusuri kemungkinan adanya penyulit atau gangguan yang mungkin dapat mengganggu kualitas hasil kehamilan, baik pada ibu maupun neonatus. ${ }^{(1)}$

Pada tahun 1992, McGarthy dan Maine mengembangkan kerangka konsep kematian ibu secara garis besar. Pada konsep tersebut ternyata proses kehamilan, persalinan dan komplikasiya adalah faktor paling dekat dengan kematian dan kesakitan ibu. Banyak determinan yang turut 
menentukan angka kematian ibu, diantaranya adalah status perempuan dalam keluarga dan masyarakat (mencakup pendidikan, pekerjaan, pendapatan dan sosial/legal), status reproduksi (umur, paritas, status marital), status keluarga dalam masyarakat (pendapatan keluarga, pendidikan, pekerjaan), akses terhadap pelayanan kesehatan (lokasi, jenis pelayanan yang tersedia, kualitas pelayanan, akses terhadap informasi), perilaku terhadap pelayanan kesehatan $(\mathrm{KB}$, asuhan antenatal, asuhan persalinan, pelayanan tradisionmal, abortus) dan banyak determinan lainnya. ${ }^{(3)}$

Penelitian ini dilakukan untuk melihat hubungan antara berbagai faktor baik internal maupun eksternal dengan keteraturan melakukan pemeriksaan antenatal, untuk menunjang program Safe Motherhood, sehingga diharapkan dapat membantu dalam penurunan angka kematian ibu.

\section{METODE}

Penelitian ini merupakan penelitian observasional analitik dengan pendekatan cross sectional. Penelitian dilaksanakan selama 2 bulan, yaitu pada bulan Oktober-November 2017, dengan mengambil tempat di Puskesmas Kebon Jeruk dan Puskesmas Tambora Wilayah Jakarta Barat Daerah Khusus Ibukota Jakarta. Sampel adalah ibu hamil yang datang memeriksakan kehamilannya di Puskesmas tersebut. Kriteria inklusi adalah ibu hamil yang sehat (tidak memiliki penyulit penyakit yang berhubungan dengan kehamilan, seperti penyakit jantung koroner atau DM), dan bersedia mengikuti penelitian. Kriteria eksklusinya adalah semua penyulit pada kehamilan yang menyebabkan kehamilan membutuhkan pemeriksaan antenatal lebih dari 4 kali kunjungan (seperti gemelli, preeklampsia, perdarahan antepartum).

Setelah mendapat penjelasan mengenai tata cara dan tujuan penelitian, subyek kehamilan yang memenuhi kriteria dan bersedia mengikuti penelitian diminta untuk menandatangani persetujuan (informed consent). Pada penelitian ini, sampel yang diperlukan dihitung dengan menggunakan rumus infinit-finit, dengan menggunakan prevalensi kunjungan pemeriksaan antenatal menurut Riskesdas 2015, yaitu $87.48 \%$ sebagai dasar perhitungan.(2) Setelah dilakukan penghitungan, ternyata dibutuhkan sampel sebanyak 105 orang. Untuk mengantisipasi adanya data yang tidak lengkap atau adanya sampel yang putus studi, maka dibutuhkan total sejumlah 121 sampel. Sampel diperoleh dengan cara consecutive sampling sampai jumlah yang dibutuhkan terpenuhi. Sebagai instrumen penelitian, digunakan kuesioner yang meliputi data karakteristik responden berupa umur, pendidikan terakhir, paritas, sosial ekonomi, jarak ke fasilitas kesehatan, dukungan suami serta pengetahuan dan sikap tentang perawatan antenatal, dan kunjungan antenatalnya.

Setelah menandatangani informed consent, subyek penelitian diminta mengisi kuesioner tersebut di atas. Data yang terkumpul selanjutnya akan diolah dengan analisis univariat dan bivariat dengan menggunakan program SPSS for Mac versi 20.0. Penelitian ini telah mendapat persetujuan Komisi Etik Riset Fakultas Kedokteran Universitas Trisakti Jakarta nomor 105/KER-FK/VII/2017.

\section{HASIL}

Telah dilakukan penelitian selama bulan Oktober-November 2017 di Puskesmas Kebon Jeruk dan Puskesmas Tambora, Jakarta Barat, dengan jumlah sampel 121 orang.

Tabel 1. Distribusi subyek berdasarkan faktor internal $(n=121)$

\begin{tabular}{cc}
\hline Faktor internal & $\mathbf{n ~ ( \% )}$ \\
\hline $\begin{array}{c}\text { Usia ibu } \\
<20 \text { tahun }\end{array}$ & $10(8.3)$ \\
$20-35$ tahun & $91(75.2)$ \\
$>35$ tahun & $20(16.5)$ \\
Paritas & $31(25.6)$ \\
$>2$ orang & $90(74.4)$ \\
$\leq 2$ orang & \\
$\begin{array}{l}\text { Pengetahuan tentang } \\
\text { kehamilan } \\
\text { Jawaban benar }<7\end{array}$ & $44(36.4)$ \\
Jawaban benar 7 & $77(63.6)$ \\
$\begin{array}{l}\text { Sikap terhadap pemeriksaan } \\
\text { antenatal }\end{array}$ & \\
Positif & $51(42.1)$ \\
Negatif & $70(57.9)$ \\
\hline
\end{tabular}

Pada Tabel 1 terlihat bahwa dari faktor internal subyek didapatkan kelompok terbanyak adalah kelompok usia 20-35 tahun (75.2\%), dengan paritas $\leq 2$ orang (74.4\%), memiliki pengetahuan yang baik dengan mampu menjawab benar 7 pertanyaan tentang kehamilan $(63.6 \%)$ dan sikap yang negatif terhadap pemeriksaan antenatal $(57.9 \%)$. 
Tabel 2. Distribusi subyek berdasarkan faktor eksternal $(n=121)$

\begin{tabular}{|c|c|}
\hline Faktor eksternal & n $(\%)$ \\
\hline \multicolumn{2}{|l|}{ Penghasilan keluarga } \\
\hline$>$ UMR & $66(54.5)$ \\
\hline$\leq \mathrm{UMR}$ & $55(45.5)$ \\
\hline \multicolumn{2}{|l|}{ Waktū tempuh ke fasilitas } \\
\hline $\begin{array}{l}\text { kesehatan } \\
\quad>30 \text { menit }\end{array}$ & $51(42.1)$ \\
\hline$\leq 30$ menit & $70(57.9)$ \\
\hline \multicolumn{2}{|l|}{ Status pekerjaan } \\
\hline Bekerja & $44(36.4)$ \\
\hline Tidak bekerja & $77(63.6)$ \\
\hline \multicolumn{2}{|l|}{$\begin{array}{l}\text { Dukungan suami terhadap } \\
\text { pemeriksaan kehamilan }\end{array}$} \\
\hline Positif & $75(38.0)$ \\
\hline Negatif & $46(62.0)$ \\
\hline
\end{tabular}

Dari Tabel 2 tampak bahwa walaupun sebagian besar subyek memiliki penghasilan keluarga yang lebih tinggai dari UMR (54.5\%), tidak bekerja $(63.6 \%)$ sehingga memiliki cukup waktu dan tinggal cukup dekat dengan fasilitas kesehatan (57.9\%), ternyata sebagian besar tidak mendapat dukungan suami untuk melakukan pemeriksaan antental (62\%).

Dari Tabel 3 tampak bahwa didapatkan hubungan faktor internal subyek yang secara statistik bermakna, yaitu antara paritas $(\mathrm{p}=0.033)$, pengetahuan tentang kehamilan $(\mathrm{p}=0.012)$ dan sikap terhadap pemeriksaan kehamilan $(\mathrm{p}=0.005)$ dengan keteraturan kunjungan pemeriksaan antenatal $\geq 4$ kali kunjungan.

Didapatkan hubungan yang bermakna antara faktor eksternal penghasilan keluarga $(\mathrm{p}=0.000)$, waktu tempuh ke fasilitas kesehatan $(\mathrm{p}=0.015)$ dan dukungan suami $(\mathrm{p}=0.000)$ dengan keteraturan melakukan pemeriksaan antenatal, tetapi tidak terdapat hubungan yang bermakna antara status pekerjaan dengan keteraturan pemeriksaan antenatal $(\mathrm{p}=0.082)$.

\section{PEMBAHASAN}

Pada penelitian ini didapatkan bahwa sebagian besar subyek penelitian merupakan kelompok dengan usia reproduksi sehat dan paritas yang baik. Namun walau sebagian besar subyek memiliki pengetahuan yang baik mengenai kehamilan tetapi ternyata memiliki sikap yang negatif terhadap pemeriksaan antenatal. Hal ini berarti bahwa pengetahuan yang cukup tidak selalu sejalan dengan sikap yang positif. Bila dikaitkan dengan faktor internal, kurangnya dukungan suami mungkin berhubungan dengan sikap yang negatif terhadap pemeriksaan kehamilan, walaupun ibu hamil memiliki pengetahuan yang cukup.

Terdapat hubungan yang bermakna antara paritas dengan keteraturan melakukan pemeriksaan antenatal. Hasil ini sejalan dengan sebuah penelitian yang menyatakan bahwa paritas $\leq 2$, ibu lebih teratur melakukan pemeriksaan kehamilan, karena ibu hamil merasa belum berpengalaman dalam hal kehamilan dan persalinan. ${ }^{(4)}$ Hasil ini bertentangan dengan hasil yang didapat oleh Lihu, yang menyatakan tidak ada hubungan antara paritas dengan keteraturan melakukan pemeriksaan antenatal. Perbedaan ini mungkin disebabkan karena perbedaan lokasi penelitian, dimana penelitian ini dilakukan di kota Jakarta Barat, sedangkan penelitian Lihu dilakukan di Gorontalo, dengan medan yang berbeda, sehingga untuk menjangkau fasilitas kesehatan menjadi lebih sulit. ${ }^{(5)}$

Pada penelitian ini terdapat hubungan yang bermakna antara pengetahuan ibu tentang kehamilan dengan keteraturan melakukan pemeriksaan antenatal. Hal ini sesuai dengan penelitian Lihu yang menyatakan bahwa

Tabel 3. Hubungan antara faktor internal terhadap keteraturan pemeriksaan antenatal

\begin{tabular}{|c|c|c|c|}
\hline \multirow[b]{2}{*}{ Faktor internal } & \multicolumn{2}{|c|}{ Keteraturan pemeriksaan antenatal } & \multirow[b]{2}{*}{$\mathbf{p}$} \\
\hline & $\begin{array}{c}\geq 4 \text { kali } \\
\mathrm{n}(\%)\end{array}$ & $\begin{array}{c}<4 \text { kali } \\
\text { n(\%) }\end{array}$ & \\
\hline $\begin{array}{ll}\text { Usia } & \\
& <20 \text { tahun } \\
& 20-35 \text { tahun } \\
& \geq 35 \text { tahun }\end{array}$ & $\begin{array}{l}3(2.4) \\
55(45.5) \\
12(9.9)\end{array}$ & $\begin{aligned} 7 & (5.8) \\
36 & (29.8) \\
8 & (6.6)\end{aligned}$ & $0.176 *$ \\
\hline $\begin{array}{l}\text { Paritas } \\
\quad 22 \text { orang } \\
\leq 2 \text { orang }\end{array}$ & $\begin{array}{c}23(19) \\
47(38.8)\end{array}$ & $\begin{array}{c}8(6,6) \\
43(35.6)\end{array}$ & 0.033* \\
\hline $\begin{array}{l}\text { Pengetahuan tentang kehamilan } \\
\text { Jawaban benar } 7 \\
\text { Jawaban benar }<7\end{array}$ & $\begin{array}{l}32(26.5) \\
38(31.4)\end{array}$ & $\begin{array}{c}12(9.9) \\
39(32.2)\end{array}$ & $0.012 *$ \\
\hline $\begin{array}{l}\text { SIkap ternadap pemeriksaan antenatal } \\
\text { Positif } \\
\text { Negatif }\end{array}$ & $\begin{array}{l}37(30.6) \\
33(27.3)\end{array}$ & $\begin{array}{l}14(11.5) \\
37(30.6)\end{array}$ & $0.005 *$ \\
\hline
\end{tabular}


Tabel 4. Hubungan antara faktor eksternal terhadap keteraturan pemeriksaan antenatal

\begin{tabular}{|c|c|c|c|}
\hline \multirow[b]{2}{*}{ Faktor eksternal } & \multicolumn{2}{|c|}{ Keteraturan pemeriksaan antenatal } & \multirow[b]{2}{*}{$\mathbf{p}$} \\
\hline & $\underset{\mathrm{n}(\%)}{\geq 4 \mathrm{kali}}$ & $\begin{array}{c}\text { < } 4 \text { kali } \\
\text { n(\%) }\end{array}$ & \\
\hline $\begin{array}{l}\text { Penghasilan keluarga } \\
\text { > UMR } \\
\text { <UMR }\end{array}$ & $\begin{array}{l}48(39.7) \\
22(18.2)\end{array}$ & $\begin{array}{l}18(14.9) \\
33(27.2)\end{array}$ & $0.000 *$ \\
\hline $\begin{array}{l}\text { Waktu tempuh ke fasilitas kesehatan } \\
\quad 30 \text { menit } \\
\leq 30 \text { menit }\end{array}$ & $\begin{array}{l}23(19.0) \\
47(38.8)\end{array}$ & $\begin{array}{l}28(23.2) \\
23(19.0)\end{array}$ & $0.015 *$ \\
\hline $\begin{array}{l}\text { Status pekerjaan } \\
\text { Bekerja } \\
\text { Tidak bekerja }\end{array}$ & $\begin{array}{l}30(24.8) \\
40(33.0)\end{array}$ & $\begin{array}{l}14(11.6) \\
37(30.6)\end{array}$ & $0.082 *$ \\
\hline $\begin{array}{l}\text { Dukungan suami } \\
\text { Positif } \\
\text { Negatif }\end{array}$ & $\begin{array}{l}57(47.1) \\
13(10.8)\end{array}$ & $\begin{array}{l}18(14.9) \\
33(27.2)\end{array}$ & $0.000 *$ \\
\hline
\end{tabular}

\section{*uji Chi Square}

responden yang mengetahui manfaat pemeriksaan antenatal akan memiliki motivasi yang lebih tinggi untuk datang dan memanfaatkan sarana pelayanan kesehatan. ${ }^{(5)}$ Penelitian lain yang dilakukan oleh Mardiyah menyatakan bahwa pengetahuan ibu hamil dapat dipengaruhi peran kader dan bidan yang memberikan informasi akan pentingnya pemeriksaan antenatal bagi ibu hamil. ${ }^{(6)}$ Hasil yang berbeda ditemukan pada penelitian Tighe yang menyatakan tidak ada hubungan antara pengetahuan ibu dengan pemeriksaan antenatal, asalkan ibu hamil mendapat motivasi dari bidan di tempat fasilitas kesehatan. ${ }^{(7)}$

Hasil analisis menunjukkan hubungan yang bermakna antara sikap ibu terhadap pemeriksaan antenatal dengan keteraturan kunjungan pemeriksaan antenatal. Suatu penelitian yang dilakukan oleh Erlina menyatakan bahwa sikap yang negatif terhadap pemeriksaan antenatal dipengaruhi oleh keluarga, seperti misalnya anggota keluarga yang lain tidak melakukan pemeriksaan antenatal secara teratur. Hal ini juga mungkin karena kurangnya informasi yang disampaikan oleh petugas kesehatan. ${ }^{(8)}$ Hasil ini juga sesuai dengan penelitian Fitrayeni yang menyatakan bahwa sikap ibu dipengaruhi oleh pengetahuan akan manfaat pemeriksaan antenatal. ${ }^{[9]}$ Dalam penelitian ini didapatkan bahwa walaupun pengetahuan ibu cukup ternyata didapatkan sikap yang negatif. Hal ini mungkin dipengaruhi oleh sikap dan dukungan suami dan anggota keluarga lain.

Tidak ditemukan hubungan yang bermakna antara usia subyek dengan keteraturan melakukan pemeriksaan antenatal $(\mathrm{p}=0.176)$. Hal ini sesuai dengan penelitian yang dilakukan oleh Jekti, yang menyatakan bahwa pemahaman pentingnya melakukan pemeriksaan antenatal tidak berhubungan dengan usia seseorang, tetapi lebih berhubungan dengan informasi yang disampaikan kepada ibu hamil. ${ }^{(10)}$ Hasil penelitian ini tidak sejalan dengan penelitian Nursal, yang menyatakan bahwa ibu yang hamil pada masa reproduksi optimal lebih teratur melakukan pemeriksaan antenatal. Nursal menyatakan usia ibu berkaitan erat dengan sikap dan pengetahuan ibu tentang kehamilan. Pada penelitian ini didapatkan bahwa walaupun sebagian besar subyek berada pada usia reproduksi yang optimal, tetapi sebagian besar ibu memiliki sikap yang negatif terhadap pemeriksaan antenatal. Hal ini mungkin berkaitan dengan faktor lain, seperti dukungan suami dan lingkungan. ${ }^{(11)}$

Pada penelitian ini didapatkan tidak terdapat hubungan yang bermakna antara status pekerjaan dengan keteraturan pemeriksaan antenatal $(\mathrm{p}=0.082)$. Hal ini sesuai dengan penelitian yang dilakukan Vitriyani yang menyatakan tidak ada hubungan antara status pekerjaan dengan keteraturan melakukan kunjungan pemeriksaan antenatal, karena lebih dipengaruhi oleh pengetahuan yang disampaikan oleh petugas kesehatan. ${ }^{(12)}$ Hasil ini bertentangan dengan penelitian Kassyou yang menyatakan bahwa salah satu faktor yang mempengaruhi kunjungan pemeriksaan antenatal adalah karena ibu yang bekerja terlalu sibuk dengan pekerjaannya sehingga tidak memiliki cukup waktu untuk memeriksakan kehamilannya. ${ }^{(13)}$ Perbedaan hasil ini mungkin disebabkan karena lokasi penelitian yang berbeda, dimana penelitian Kassyou dilakukan di Ethiopia, Afrika, sehingga mungkin dibutuhkan waktu tempuh yang lebih lama untuk menjangkau fasilitas kesehatan dibanding subyek pada penelitian ini. 
Penghasilan keluarga merupakan hal yang berhubungan bermakna dengan keteraturan melakukan pemeriksaan antenatal. Hal ini sesuai dengan penelitian Mardiyah yang menyatakan bahwa ibu dengan penghasilan keluarga yang kurang, lebih jarang melakukan pemeriksaan kehamilan dibanding dengan ibu dengan penghasilan keluarga yang cukup. ${ }^{(6)}$ Hasil serupa juga ditemukan pada penelitian Umayah yang menyatakan bahwa penghasilan keluarga yang kurang menjadi salah satu faktor penghambat untuk memberikan prioritas pada pemeriksaan kesehatan dibanding dengan kebutuhan pokok yang lain. ${ }^{(14)}$ Hal ini mudah dipahami, karena dengan penghasilan keluarga yang kurang, maka akan sulit untuk mengunjungi tempat fasilitas kesehatan karena walaupun pemeriksaan antenatal diberikan secara cuma-cuma tetapi tetap membutuhkan biaya untuk dapat mencapai tempat fasilitas kesehatan.

Waktu tempuh ke fasilitas kesehatan juga merupakan hal yang berhubungan secara bermakna dengan keteraturan pemeriksaan antenatal. Hal ini serupa dengan hasil penelitian Mardiyah yang menyatakan bahwa lokasi fasilitas pemeriksaan kehamilan yang kurang strategis akan mempersulit ibu hamil untuk melakukan kunjungan pemeriksaan kehamilan. ${ }^{(6)}$ Hal berbeda dinyatakan oleh Vitriyani yang menyatakan bahwa jarak tempuh tidak mempengaruhi kunjungan pemeriksaan antenatal asalkan ibu hamil memiliki pengetahuan yang cukup mengenai pentingnya pemeriksaan kehamilan bagi kesehatan ibu dan janin dalam kandungan. ${ }^{(12)}$ Perbedaan hasil ini mungkin disebabkan karena lokasi penelitian yang berbeda. Penelitian Vitriyani mengambil tempat di Kabupaten Sukoharjo Jawa Tengah, dimana masyarakatnya terbiasa berjalan kaki sehingga jarak dan waktu tempuh ke fasilitas kesehatan tidak menjadi faktor penghambat, dibanding masyarakat kota yang lebih mengandalkan alat transportasi.

Dukungan suami juga merupakan faktor eksternal yang menunjukkan hubungan yang bermakna dengan keteraturan melakukan pemeriksaan antenatal. Hal ini sejalan dengan hasil dari penelitian Mukaromah yang mendapatkan bahwa dukungan keluarga terutama suami menjadi faktor pendorong yang memotivasi ibu untuk lebih teratur melakukan pemeriksaan kehamilan. $^{(12)}$ Hal ini sangat mudah dipahami karena kebiasaan dan adat istiadat di Negara kita, dimana seorang isteri membutuhkan izin suami untuk bisa meninggalkan rumah untuk tujuan apapun. Bila suami tidak mendukung dan tidak memberikan izin, maka akan sulit untuk ibu pergi memeriksakan kehamilannya.

\section{KESIMPULAN}

Terdapat hubungan yang bermakna antara faktor internal paritas $(p=0.033)$, pengetahuan tentang kehamilan $(\mathrm{p}=0.012)$ dan sikap ibu hamil terhadap pemeriksaan kehamilan $(\mathrm{p}=0.005)$ serta faktor eksternal penghasilan keluarga $(\mathrm{p}=0.000)$, waktu tempuh ke fasilitas kesehatan $(\mathrm{p}=0.015)$ dan dukungan suami $(\mathrm{p}=0.000)$ dengan keteraturan melakukan pemeriksaan antenatal. Tidak terdapat hubungan antara usia $(\mathrm{p}=0.176)$ dan status pekerjaan $(\mathrm{p}=0.082)$ dengan keteraturan kunjungan pemeriksaan antenatal.

Disarankan kepada petugas kesehatan untuk memberikan penyuluhan secara berkala kepada masyarakat sehingga dapat meningkatkan pengetahuan $\mathrm{ibu}$ hamil tentang pentingnya pemeriksaan kehamilan secara teratur, dan diharapkan dapat membentuk sikap yang positif terhadap pemeriksaan antenatal. Penyuluhan juga sebaiknya melibatkan suami dan keluarga sehingga ibu hamil mendapat dukungan dari keluarga, khususnya suami dalam melakukan pemeriksaan kehamilan secara teratur.

Disarankan juga untuk melakukan penelitian dengan jumlah sampel yang lebih banyak dengan lokasi penelitian yang bervariasi sehingga dapat memberikan gambaran yang lebih tepat mengenai hubungan berbagai faktor internal dan eksternal terhadap keteraturan pemeriksaan antenatal.

\section{DAFTAR REFERENSI}

1. Sarwono P. Buku ilmu kebidanan. Jakarta: Yayasan Bina Pustaka; 2010.

2. Kementrian Kesehatan. Profil Kesehatan Indonesia 2014. Yudianto, Budijanto D, Hardhana B, Soenardi TA, \{Eds\} Kementeri Kesehat Republik Indones Jakarta Kementrian Kesehat Republik Indones. 2015;

3. Martaadisoebrata D, Sastrawinata S, Saifuddin AB. Bunga Rampai Obstetri dan Ginekologi Sosial. Jakarta: YBPSP. 2005;

4. Widiantari NKN, Suariyani LP, Karmaya M. Association of Socio Demographic Characteristics and Husband Social Supports to the Participation 
of Mother in Antenatal Class. Public Heal Prev Med Arch 2016;4(1):64-74. DOI: https://doi. org/10.24843/PHPMA.2016.v04.i01.p09

5. Lihu FA, Umboh JML, Kandou GD. Analisis Hubungan Antara Faktor Internal dan Faktor Eksternal Ibu Hamil Dalam Melakukan Tindakan Antenatal Care Di Puskesmas Global Limboto Kabupaten Gorontalo. JIKMU 2015;5(5):427-35.

6. Mardiyah UL, Herawati YT, Witcahyo E. Faktor yang Berhubungan dengan Pemanfaatan Pelayanan Antenatal oleh Ibu Hamil di Wilayah Kerja Puskesmas Tempurejo Kabupaten Jember Tahun 2013 (Correlated Factors of Antenatal Services Utilization by Pregnant Women at Community Health Center of Tempurejo. Pustaka Kesehat. 2014;2(1):58-65.

7. Tighe SM. An exploration of the attitudes of attenders and non-attenders towards antenatal education. Midwifery. Elsevier; 2010;26(3):294303. DOI:10.1016/j.midw.2008.06.005

8. Erlina R, Larasati TA, Kurniawan B. Faktor-faktor yang mempengaruhi ibu hamil terhadap kunjungan pemeriksaan kehamilan di Puskesmas rawat inap Panjang Bandar Lampung. Medical Journal of Lampung University 2013;2(4):29-34.

9. Fitrayeni F, Suryati S, Faranti RM. Penyebab Rendahnya Kelengkapan Kunjungan Antenatal Care Ibu Hamil Di Wilayah Kerja Puskesmas Pegambiran. J Kesehat Masy Andalas. 2017;10(1):101-7. https://doi.org/10.24893/ jkma.10.1.101-107.2015

10. Jekti RP, Mutiatikum D. Hubungan Antara Kepatuhan Ante Natal Care Dengan Pemilihan Penolong Persalinan. J Kesehat Reproduksi. 2011;1(2):84-91.

11. Nursal DGA, Tamela P, Fitrayeni. Faktor Resiko Yang Berhubungan Dengan Kejadian Preeklampsia Pada Ibu Hamil di RSUP. DR M Djamil Padang Tahun 2014. J Kesehat Masy Andalas 2015; 10(1):38-44

12. Vitriyani E, Kirwono B, Firnawati AF. FaktorFaktor Yang Berhubungan Dengan Pemeriksaan Antenatal Care (ANC) K1 Ibu Hamil Di Kecamatan Polokarto Kabupaten Sukoharjo. Jurnal Kesehatan 2012;5(2):149-56.

13. Kassyou H. Factors affecting antenatal care attendance in Maichew Town, Southern Tigray [thesis]. Sch Grad Stud Addis Ababa Univ. 2008.

14. Umayah RF. Hubungan Tingkat Ekonomi Ibu Hamil Dan Tingkat Kepuasan Dengan Keteraturan Pemeriksaan Kehamilan DI RB \& BP Asy-Syifa' PKU Muhammadyah Wedi Klaten. Universitas Sebelas Maret; 2010. 